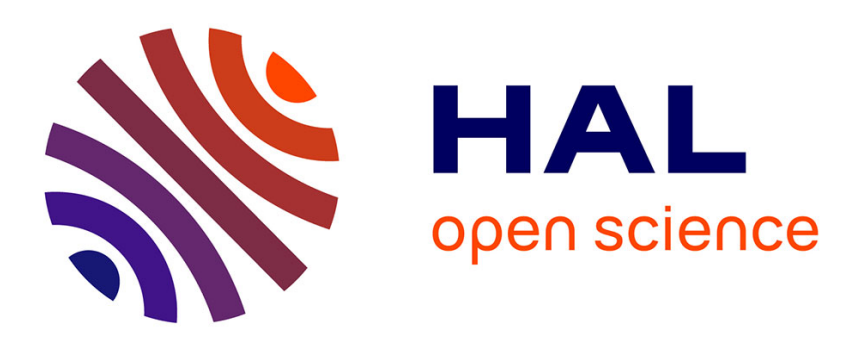

\title{
The History of Transhumanism (cont.)
}

Olivier Dard, Alexandre Moatti

\section{To cite this version:}

Olivier Dard, Alexandre Moatti. The History of Transhumanism (cont.). Notes and Queries, 2017, 64 (1), pp.167-170. 10.1093/notesj/gjw256 . halshs-03314685

\section{HAL Id: halshs-03314685 https://shs.hal.science/halshs-03314685}

Submitted on 5 Aug 2021

HAL is a multi-disciplinary open access archive for the deposit and dissemination of scientific research documents, whether they are published or not. The documents may come from teaching and research institutions in France or abroad, or from public or private research centers.
L'archive ouverte pluridisciplinaire HAL, est destinée au dépôt et à la diffusion de documents scientifiques de niveau recherche, publiés ou non, émanant des établissements d'enseignement et de recherche français ou étrangers, des laboratoires publics ou privés. 


\section{The History of Transhumanism (cont.)}

Olivier DARD, Alexandre MOATTI

Notes and Queries, Volume 64, Issue 1, March 2017, Pages 167-170, https://doi.org/10.1093/notesj/gjw256

Publié le 9 février 2017

In an article entitled 'The History of Transhumanism', published in Notes \& Queries in July 2015, Peter Harrison and Joseph Wolyniak ${ }^{1}$ rightly point out a common error found in standard academic articles and on the Internet-particularly Wikipedia, which cites these academic sources in good faith-according to which the word transhumanism was 'invented' by Julian Huxley in 1957 (or even in 1927, certain sources claim). Referring to the use of the term by the Canadian essayist W. D. Lighthall (1857-1954) - who evokes 'St Paul's transhumanism'-the authors draw a connection between this religious use of the term (transhumanism as man's capacity to transcend the human condition in his encounter with God) and Dante's use of the term in The Divine Comedy (through the Italian verb he coined, trasumanar, which Carey, the English translator of Dante, translated in 1814 as transhuman change).

As the authors suggest, tracing the history of the word transhumanism is an important matter given the contemporary upsurge in the use of the term. The fact that the term is practically identical in the Latin and Anglo-Saxon ${ }^{2}$ languages facilitates this research and makes it all the more useful. Indeed, understanding how the word made its (re)appearance in the evolutionist discourses of the 1930s to the 1960s sheds light on contemporary usage of the term. After correctly noting that Julian Huxley used the term in a lecture of 1951, Harrison and Wolyniak suggest that he may have read the word in Lighthall when he was looking for an alternative to evolutionary humanism to describe his own scientific utopia. This is a plausible hypothesis, but we would like to introduce another to the debate.

${ }^{1}$ Wolyniak had made the same point in his article in the collectively authored Religion and Transhumanism: The Unknown Future of Human Enhancement, ed. Calvin Mercer and Tracy J. Trothen (Santa Barbara, 2015). Independently of Wolyniak, we had noted the same inconsistencies in the dating of the first use of the word.

${ }^{2}$ For example, transhumanisme in French, transhumanismus in German, and transumanismo in Spanish. 
The idea that mankind is capable of transcending the human condition to attain a state of 'transhumanism' is pervasive in the utopias of the New Man of the 1930s. These utopias tend in two ostensibly different directions. The first is religious; it is concerned with the encounter between man and God and can be found in Lighthall, writing in 1940, as well as in the work of the French Jesuit palaeontologist Pierre Teilhard de Chardin (1881-1955). The second is secular and scientific. It is concerned with mankind transcending the human condition through science and technology. This is the transhumanism of Julian Huxley, among others: a Religion without Revelation; ${ }^{3}$ indeed, a religion of mankind. It is this latter conception that one finds among transhumanist movements today, which, aside from a few rare exceptions, no longer invoke religion (in a revelatory sense). Yet at one time, indeed until the 1960s, the two conceptions coexisted and were compatible. Although its ends were different, religious transhumanism itself drew extensively on science, in particular evolutionist biology (in Teilhard) and cosmology (in Lighthall).

As Harrison and Wolyniak emphasize, although Lighthall's 'Pauline transhumanism' is apparently distinct from Huxley's vision, in reality the two conceptions could not be entirely removed from one another, for they shared a strong scientific foundation. Although Lighthall uses the term in the first context, it is in the second (non-religious) context that one finds the word transhumanisme being used in the work of the French engineer Jean Coutrot (1895-1941) in the 1930s. The life and work of this polytechnician and pioneer of technocracy have long been forgotten: he was both a theorist and a 'prophet' of the rational organization of the economy and of human society in France in the 1930s. ${ }^{4}$

The word transhumanisme appears in a lecture that Coutrot delivered on Sunday 28 May 1939 at the Entretiens de Pontigny (Yonne), which he himself organized. ${ }^{5}$ True to form, his reasoning was sweeping yet vague, paying little heed to precise definitions. Assuming a prophetic role, he frequently looks forward to the next stage in the evolution of the New Man. Indeed, it is a 'transhumanist précis' [précis de transhumanisme] that he delivers. ${ }^{6}$

${ }^{3}$ Julian Huxley, Religion without Revelation (London, 1927).

${ }^{4}$ Olivier Dard, Jean Coutrot. De l'Ingénieur au Prophète (Besançon, 1999).

${ }^{5}$ It is possible that this word appears a little earlier in the writings of Coutrot, because in May 1939 a commentator evoked Coutrot's 'schémas transhumanistes' (Pierre Aubé, 'Faisons le point', La Semaine céphéenne, iii (15 May 1939), cited in Dard, Jean Coutrot, 359).

${ }^{6}$ Dard, Jean Coutrot, 379. 
According to Coutrot, transhumanisme was an ideology in which various human types (the sensorial, conformist, intuitive, and rationalist types-Coutrot was keen on psychology) would 'come together around Truth'. Here the prefix -trans is used in the sense of the traversal and grouping of various categories. But Coutrot also uses -trans in the sense of an evolution through time. This is closer to the current meaning of the term and similar to Huxley's notion of evolutionary humanism: the human race has changed, is able to change, and will change again; the future 'human sciences' in which humanity places its hopes - which will call more upon the spirit of geometry (i.e. mathematics) than the spirit of finesse-should provide us with a better understanding of this evolution from humanism to transhumanism. Although his understanding of the term is still in flux in the lecture of May 1939, Coutrot also alludes to an overarching -trans presiding over various humanisms (and not various human types). This is the conclusion of his lecture: 'Taken together, the different aspects of these various humanisms make up what one might call transhumanism' [L'ensemble de tous ces aspects d'humanismes divers constituent ce que nous pouvons appeler le transhumanisme].

Even though the meanings he invokes are rather varied, Coutrot is conscious of the scope of his new word. In a letter dated 28 August 1939 to the famous doctor Alexis Carrel (1873-1944, Nobel Prize in Physiology and Medicine 1912), with whom he corresponded, he writes: 'Please accept, dear doctor, the expression of my kindest and most "transhumanist" sentiments (you will find the explanation of this indispensable neologism in my texts). ${ }^{7}$

Yet surprisingly - or not, as the case may be-Coutrot and Huxley's paths were intertwined. Coutrot knew Aldous Huxley (1894-1963), Julian's brother, very well; the two men were the same age and they and their wives were friends. ${ }^{8}$ Did Coutrot mention the term to Aldous before the war (he died in 1941), and did Aldous in turn mention it to his brother, Julian, who would himself use it in a lecture delivered in 1951? Or was the opposite true? Might Julian Huxley have already had the term in mind and discussed it with Aldous,

${ }^{7}$ Cited by Alain Drouard, 'La Fondation pour l'étude des problèmes humains et l'organisation de la recherche en sciences sociales en France', Cahiers pour l'histoire du CNRS, ix (1990) (online).

8 'The Coutrots had known Aldous and Maria Huxley since the 1920s. Even after their move to California, the Huxleys remained in touch with the Coutrots. Maria Huxley wrote to them: 'We so often think about you both ..."' [Le couple Coutrot connaît Aldous et Maria Huxley depuis les années vingt. Installés en Californie, les Huxley restent fidèles aux Coutrot. Maria Huxley leur écrivant: « Nous pensons tant à vous deux ...»], in Dard, Jean Coutrot, 113. 
who in turn mentioned it to Coutrot - who was quick to seize upon anything new? We will probably never know for sure.

The issue of the early uses of the term transhumanism from the 1930s onwards therefore remains open to debate. This is also true of the ways in which the term was reused by later authors, namely Julian Huxley in 1951, but also Teilhard de Chardin in 1949, who writes: 'Liberty: that is to say, the chance offered to every man (by removing obstacles and placing the appropriate means at his disposal) of "trans-humanizing" himself.' $\mathrm{We}$ cite the Jesuit Teilhard de Chardin because he himself was a central figure in this debate in the 1930s and 1940s. ${ }^{10}$ Although he did not participate in Coutrot's Entretiens de Pontigny, he was notable in his absence; indeed, he was constantly 'evoked and invoked'. ${ }^{11}$ Furthermore, Julian Huxley wrote the preface to the English translation (published in 1959) of Teilhard's authoritative work, Le Phénomène humain (1955). ${ }^{12}$ This goes to show that the boundary between (Teilhard's) Christian transhumanism and (Huxley's) 'religion (of man) without revelation' - the two contexts evoked above - is not an easy one to map.

To conclude, this brief study also hints at the fact that, above and beyond the word itself, these concepts remain polysemic or even vague (notably in Coutrot, and to a lesser extent in Huxley). The precise definition of terms has never been one of the characteristics of utopias-from Saint-Simon to the 1930s utopias of the New Man. In the realm of vocabulary, as elsewhere, any departure from ambiguity is often detrimental to one's cause. It is possible that, even in the contemporary transhumanist utopia, the term remains hazy. Although its definition may sharpen with every technical advance, so does the imaginative freight it carries in tow! The word therefore becomes a marker of a perpetually ulterior

${ }^{9}$ Pierre Teilhard de Chardin, 'The Essence of the Democratic Idea: A Biological Approach', in The Future of Mankind, trans. Norman Denny (New York and Evanston, 1959) [French orig. L'A venir de l'Homme (Paris, 1959), 360]. Later on Teilhard would use the (more Latin and less Anglo-Saxon) word ultra-humain, which has subsequently been taken up by his many commentators. It is possible that Teilhard wished to distance himself from the term transhuman-which had been 'pre-empted' by Coutrot before the warparticularly because his own purposes were rather different.

10 The philosopher Eric Steinhart (William Paterson University) has stressed Teilhard's historical importance in the study of transhumanism ('Teilhard de Chardin and Transhumanism', Journal of Evolution and Technology, (December 2008), 1-22).

${ }^{11}$ For more on the 'coincidences and convergences' between Teilhard and Coutrot, see the detailed discussion of this topic in Dard, Jean Coutrot, 371-6.

12 The Phenomenon of Man, trans. Bernard Wall, introduction by Sir Julian Huxley (New York, Evanston and London, 1959). A new translation by Sarah Appleton-Weber was published in 1999 under the title The Human Phenomenon. 
state, 'making constant appeals to the imaginary' [solliciter constamment l'imaginaire]. ${ }^{13}$ In any event, from a strictly historical point of view, it is useful and profitable to examine how the word transhumanism was used before the twentieth century, how it underwent a resurgence from the 1930s onwards (or even before), how it was defined at that time, and how it has given rise to various semantic variations. ${ }^{14}$

13 Michèle Robitaille (Université de Montréal), 'Le transhumanisme comme idéologie technoprophétique', Futuribles, ccclxx (January 2011), 57-70.

${ }^{14}$ Such as ultra-humain in later works by Teilhard (see note 9) or surhumain in the work of the French biologist Jean Rostand (1894-1977). 